\title{
A világi és a spirituális hatalom kapcsolata a reformáció korában ${ }^{1}$
}

\section{Relationship between Secular and Spiritual Power During the Period of Protestant Reformation}

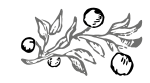

\section{Összefoglalás}

Jelen tanulmány a reformáció két legfontosabb gondolkodójának (Luther Márton és Kálvin János) államról és politikáról szóló gondolatait elemzi. A tárgyalás fó fókusza az állami (világi) és egyházi (szellemi) hatalom elválasztásán van. Eszmetörténeti kontextusban helyezve azt próbálom bizonyítani, hogy már a középkorban is megvoltak a két hatalom elválasztásának csírái, de az állami hatalom szekularizációjának elóképe a 16. századi politikai gondolkodásban jelent meg.

Kulcsszavak: szekularizáció, reformáció, állam és egyház elválasztása, Luther, Kálvin

\section{Summary}

In this paper the political theories of the Age of Reformation are analysed through the ideas of its two main figures (Martin Luther and John Calvin). The emphasis is on the division between the state (secular) and church (spiritual) power. In a historical context I present my proposition that the intellectual roots of the secularization of state power started sometime in the Middle Ages, but it appeared in a definite form in the 16th century.

Keywords: secularization, Reformation, separation of state and church, Luther, Calvin

Dr. Kevevári István, adjunktus, Nemzeti Közszolgálati Egyetem, ÁKK Európai Állam- és Jogtörténeti Intézet (Kevevari.Istvan@uni-nke.hu). 
Kevevári István: A világi és a spirituális hatalom kapcsolata a reformáció korában

„Minden lélek engedelmeskedjék a felettes hatalmaknak, mert nincsen hatalom mástól, mint Istentôl, ami hatalom pedig van, az Istentôl rendeltetett."

Róm 13,1

\section{BEVEZETÉS}

A reformáció az európai kultúrtörténetben mindenképpen cezúrának tekinthetô. Jelen tanulmányom azt vizsgálja, hogy a modern állam fogalmi kereteinek kialakulása tekintetében milyen jelentősége van ennek a korszaknak. A Luther Márton nevével fémjelzett szellemi áramlat (amelynek azonban sokkal mélyebb és régebbi gyökerei voltak) elsôsorban a korszak hitéletét kívánta megújítani, nem voltak markáns politikai törekvései, habár az egyén lelkiségének megújításából logikusan következtek olyan politikai jellegú elképzelések, amelyek - mint látni fogjuk - nem voltak újító jellegúek, de hatástörténetüket tekintve rögzítették az állam szerepére vonatkozó középkori viták végsố válaszát.

Tanulmányomban Luther Márton és Kálvin János nézeteit szeretném bemutatni, egyúttal kitekintenék gondolataik szellemi előzményeire. A tézisem az, hogy a világi és szellemi (illetve spirituális) hatalom viszonyára vonatkozó gondolataikra a középkori viták kikristályosodásaiként lehet tekinteni. A reformáció álláspontja nem is igazán a világi és a spirituális hatalom megkülönböztetése tekintetében novum, hanem abban, ahogy ez a megkülönböztetés megjelent abban a szellemi környezetben, amelyben a keresztény univerzalizmusra már nem lehetett számítani sem az egyén, sem a politikai közösség életében. A reformáció előtti keresztény világban az egyén létének célja transzcendentális volt: a boldogság vagy a közjó elválaszthatatlan volt az egyén üdvözülésétôl. Azonban a 16. századra az addigi vallásos élet egyfajta válságát lehetett tapasztalni, amelynek reflexhatásaként az ágostoni kegyelemtan újraéledését tapaszthatjuk (MacCulloch, 2011:102-151; Chadwick, 2003:88), amelynek messzemenó következménye volt a világi politika szerepére vonatkozóan is. Azonban Birkás Antal felhívja a figyelmet arra, hogy a schola Augustiniana moderna nem volt olyan egységes, mint ahogy azt például MacCulloch és Chadwick mutatni kívánják (Birkás, 2011:24, 31).

A korszak egyik legfontosabb teológiai kérdése az üdvözülés mikéntje volt, még inkább az, hogy a hívôk e világi tettei miként tudják transzcendentális céljukat beteljesíteni, illetve elôsegíteni. A korszak purgatóriumkultusza azt vallotta, hogy az egyén képes tenni a túlvilági üdvözüléséért. Azonban ez a hit olyan vadhajtásokat produkált, amelyekre komoly iparágak épültek (így például a Luther kapcsán előkerülô búcsúcédulák árusítása). Luther és kortársai Szent Ágoston szigorú kegyelemtanáig nyúltak vissza, amikor a korszak jellegzetes teológiai elveit megfogalmazták. Ezeket az elveket öt solában lehet összefoglalni: sola gratia (az ember csak Isten kegyelméból üdvözülhet), sola fide (csak a hit által lehet üdvözülni), solus Christus (egyedül Krisztus a közvetítő Isten és ember között), sola scriptura (a hit forrása egyedül a Szentírás), sola Deo gratia (egyedül Istené a dicsôség). Az Isten kegyelméból, hit általi üdvözülés alapvetô 
változást hozott, hiszen a korábbi középkori királyi ethosznak szerves része volt, hogy a világi uralkodó a klérussal szövetségben (változó alá-fölé rendeltségi viszonyban) tesz azért, hogy elômozdítsa az egyház tagjainak (a laikus hívek és a papság együtt mint „Krisztus teste”) üdvösségét. A továbbiakban elôször is a középkori politikai gondolkodás fóbb áramlatait szeretném összefoglalni a világi és szellemi hatalom szempontjából.

\section{Világi hatalom és szellemi hatalom a középkorban}

A középkori politikai gondolkodás központi problémája mindig is a fejedelmi vagy világi hatalom helyének és szerepének meglelése volt a teremtésben. A jelentôségét tekintve két fố gondolati irányt különböztethetünk meg:

1. A „két kard” metaforájával megjelölhető elméletek I. Gelasius pápa I. Anastasius keletrómai császárnak írott 494-es levelére vezethetôk vissza, amelyben a püspöki és a királyi hatalom egyidejú létezését hangsúlyozzák: „két dolog van, ami ezt a világot kormányozza: a püspökök megszentelt tekintélye (auctoritas sacra pontificum) és a királyi hatalom (regalis potestas)" (Canning, 2002:61). Itt a világi és a szellemi/egyházi hatalom egyfajta egységét lehet megfigyelni, a két hatalom ugyanazon teremtett rendból egészében találja meg a saját helyét. Magát a két kard metaforáját Nagy Károly frank császár nevelője és tanácsadója, Alkuin használta először, majd Gottschalk elevenítette fel analógiaként a regnum és a sacerdotium kapcsolatának megjelölésére (Canning, 2002:80, 145).

2. Szent Ágoston eszkatológiai keretbe foglalja a földi és a mennyei világ dualitását. A De civitate Dei (Isten városa) címú múvében a földi politikai világ létét a búnbeeséstôl vezeti le, amely a patrisztika korának egyik általános nézete volt. A búnbeeséssel az ember eredeti természete elhomályosodott, elôtte az emberek szabadok és egyenlôek voltak, ember és ember között nem volt hatalmi viszony, azt csak a búnbeesés hozta el (Canning, 2002:68). A világban két város van: Isten városa (civita Dei) és a földi város (civitas terrena): „Két szeretet építette a két várost: a földit az istentagadó önszeretet, a mennyeit az öntagadó istenszeretet.” A két város eszkatológiailag hatalmas távolságra van egymástól, ám a földi létezésben a két civitas (város, vagy tovább értelmezve: közösség) menthetetlenül összekeveredett, és eme két város - ahogy Joseph Canning fogalmaz - „csak az utolsó ítéletkor fog szétválni” (Canning, 2002:69). A földi városnak semmi köze az ember túlvilági céljaihoz. Míg Isten városa az emberek olyan közössége, amelyet a szeretet törvénye hat át, addig a világi város az a hely, ahol a hívô keresztényeknek fizikailag szükségszerúen egzisztálniuk kell, de ha az igazságosság nem hatja át a létezés e földi szféráját, akkor valójában nem beszélhetünk másról, csak egy kiterjedt rablóbandáról.

A két elméleti irány közül a középkor jelentôs részében az elsố irány dominált, a földi búnös világban múködő hatalom és az igazi, keresztény, lelki világ radikális szembenállása sokáig inkább az olyan eretnekmozgalmakban volt jelen, mint például a katarok. A reformáció egyik eszmetörténeti fơ jelentősége éppen az volt, hogy a világi hatalom és az egyház kapcsolatát nem csupán politikai-hatalmi problémaként 
kezelte, hanem az egyén lelkiségének egy fontos kérdését is felvetette: szabad-e tennie és képes-e tenni a világi hatalom az egyén lelki üdvéért? Hogy kicsit elôreszaladjak, tanulmányom központi alakjai (Luther és Kálvin) azt vallják, hogy habár mind két ország vagy kormányzat az isteni rend egészében helyezkedik el, végeredményben a világi hatalomnak nincsenek eszközei az egyén megváltásához, mert az üdvözüléshez a kulcs Isten rendelésében van.

A terjedelmi korlátokra tekintettel a világi és a szellemi hatalom viszonyára vonatkozó középkori elméletek fố vonalait és állomásait a következóképpen foglalnám össze:

Elsônek Gelasius pápa korábban idézett levelét emelném ki, amely alapvetôen meghatározta a politikai gondolkodás kereteit a középkorban. Ha általános képet szeretnénk adni, akkor a középkorban a legfontosabb kérdések, amelyek uralták a politikai diskurzust: A királyi és püspöki hatalom kettôséből kinek van elsôbbsége, és melyik honnan ered? Kitől ered a királyi hatalom? Istentől közvetlenül, vagy a papi rend közvetítésével? A király egyházi személynek számít-e?

A világi és a szellemi hatalom funkcionális szétválása, de célját tekintve egysége jellemzi a kort. A kora középkorban a király szerepe az egyházon belül legalábbis kérdéses volt. A teokratikus monarchiában a királynak fontos szerep jutott az alattvalói szellemi vezetésében. Fontos kiemelni, hogy amikor egyházról beszélünk, akkor itt nem a szúken vett klérust kell érteni, hanem a klérust és a laikus híveket együtt. Tehát, amikor a királynak az egyház feletti hatalmáról beszélünk, akkor az Nyugat-Európában a keresztény politikai közösség feletti politikai hatalom gyakorlását jelenti. A német-római császár helyzete még speciálisabb, hiszen Nagy Károly után eme cím alatt a régi római császárok hatalmának jogfolytonosságát is értették. Nagy Szent Gergely pápa a 7. században még önmagát mint a római császár alattvalóját látta, és elismerte, hogy a császárnak mint a világi hatalom fejének van beleszólása a vallási ügyekbe (Canning, 2002:64).

Sevillai Szent Izidor a 7. században a királyi és az egyházi hatalom funkcionális elkülönülését vallotta, azonban nézetei szerint, céljaikat tekintve, egységben álltak: a király kényszerrel próbálja az egyház tagjait és alattvalóit az üdvösségre vezetni, ha arra a klérus tanítói hivataluknál fogva nem képesek. A szúken vett egyháznak a feladata „megfogalmazni és tanítani a keresztény társadalmi normákat” (Canning, 2002:48).

A királyi hatalom eredetére az érett középkorig idôben három egymást követô koncepciót lehet megkülönböztetni. Az elsô a páli nézet, mely szerint minden hatalmat Isten szentesít („Minden lélek engedelmeskedjék a felettes hatalmaknak, mert nincsen hatalom mástól, mint Istentól, ami hatalom pedig van, az Istentool rendeltetett” Róm 13,1). A második szerint az uralkodó közvetlenül Istentool kapja a hatalmát (ez a nézet a kora középkori barbár királyságokban volt jellemzô), a domináns nézet pedig az volt, hogy a király „isten kegyelméból (rex de gratia) vagy Isten segítségével” uralkodik (Canning, 2002:36). Az Alkuin által megfogalmazott két kard metaforájában is lényegében az a kérdés, hogy a világi hatalmat jelképezô kard miként kerül a fejedelem kezébe. Az egyik megközelítés szerint eleve a királyé a világi hatalmat jelképezó kard, más vélekedés összefüggésbe hozható a koronázási rituálé felkenési aktusával. 
A 10. századra egyre inkább uralkodóvá vált az a nézet a klérus részérôl, hogy a királyi cím kiadása szentség, amely felett az egyház tagjai diszponálnak. Ennek jelentôségét nem lehet lebecsülni, mert azt jelentette a világi urak számára, hogy a hatalmukat csak közvetve kapják, egyfajta kegyként, amelyet a szellemi hatalom birtokosai közvetítenek és adnak át, de bármikor visszavehetik (ez lesz a 11. századi invesztitúraharcok egyik legfontosabb vitapontja).

A pápa és a császár, illetve a világi urak viszonyának vizsgálata során két fogalmat fontos kiemelni, amely a két hatalom viszonyának más-más modelljét jelképezi: a hierokratikus és a dualista modellt. A hierokratikus modell szerint a pápa - mint Szent Péter utódja - az egész egyház feje, minden hatalom pápai jóváhagyással keletkezik, és a pápának joga van felmenteni az alattvalókat a húbéri esküjük alól a nem keresztényi módon uralkodó világi fejedelmekkel szemben; a pápa közvetíti a hatalmat Istentôl a fejedelemnek. Ezzel szemben a dualista megközelítés szerint a pápai hatalom alapvetôen spirituális jellegú, és a pápának semmilyen előjoga sincs a világi ügyekbe való beleszólásba (Canning, 2002:139).

VII. Gergely fellépése fordulópontot jelentett az egyház történetében. Az 1075-ben kiadott Dictatus Papae lényegében a pápai hatalom kizárólagosságát rögzítette nem csupán a klérus, hanem a világi fejedelmekkel (így elsôsorban a német-római császárral) szemben is. Az invesztitúraharcok során mind a császári, mind a pápai törekvések mellett is bôséges vitairat keletkezett, amelyben egyik vagy másik fél próbálta a császári hatalom függetlenségét megvédeni a pápai hatalomtól, vagy a pápai hatalom felsôbbrendúségét rögzíteni a világi urakkal szemben. A vitából most csak Aacheni Gottschalk 1076-os írását emelném ki, amely az alkuini két kard elméletet felelevenítve a császár mellé állt, és azt vallotta, hogy a világi és spirituális hatalom különáll. VII. Gergely pápa fố búne szerinte éppen az volt, hogy a két hatalom lényegi különbségét figyelmen kívül hagyva, magához kívánta ragadni a világi hatalom kardját, és egyesíteni akarta azt a lelki hatalommal.

A két hatalom konfliktusa igazán sosem jutott nyugvópontra, és folyamatos vitákat generált a reformáció koráig. Az 1122. szeptember 23-i wormsi konkordátum egyedül a püspöki hatalom kettôs természetét rögzítette: egyfelól rendelkeznek világi hatalommal (amelyet regáliaként, királyi haszonvételként kapnak, így itt a világi uralkodók alá rendeltek fôszabály szerint), míg spirituális hatalmukat tekintve függetlenek a világi fejedelmektôl (Pierard, 1994:86).

\section{A REFORMÁCIÓ KÖZVETLEN ELÓZMÉNYEI ÉS OKAI}

A 16. század elejére az egyház és a pápai hatalom spirituális válságát tapasztalhatjuk meg: a „reneszánsz pápák” egyre inkább világi uralkodóként jelentek meg (ennek egyik tipikus példájaként II. Leó pápát szokták megjelölni), ezzel egy idôben a szellemi-spirituális ügyek háttérbe húzódtak. Erre a válságra kívántak választ adni a reformáció képviselői is, akik elsôsorban teológusok és nem politikai gondolkodók voltak, így az államra és a politikai gondolkodás fejlődésére a hatásuk indirekt volt.

A reformáció közvetlen okaiként hagyományosan a korszak egyházi életének romlottságát, a búcsúcédulák árusítását és a világi és egyházi hatalom képviselôinek vetél- 
kedését lehet megjelölni. A reformáció mint mozgalom elsôdlegesen azt a célt túzte ki maga elé, hogy korának egyházi életét megújítsa oly módon, hogy a katolikus egyházat visszavezessék az ôsegyház eredeti elveihez mind szervezetileg, mind spirituálisan. Tehát nem arról van szó, hogy a reformáció fốvonalbeli képviselôi valami radikálisan mást és újat akartak volna: hitük szerint mindenki a megelôzố másfél évezred dogmáit és egyházi hagyományait kívánta leépíteni, hogy a kereszténység igazi eszméjének megfelelốn élhessék meg a hitet.

Mindez minden bizonnyal összefüggésbe hozható azzal az antik történelemszemlélettel, amely szerint az egymást követô nemzedékek mindig rosszabbak (mind erkölcseiket, mind képességeiket tekintve), és távolabb kerülnek a múltbéli aranykortól. Lényegében a középkorban is minden uralkodói törvényhozás és „reform” azt a célt szolgálta szavakban, hogy a nép és a nemesség ôsi jogaikba legyenek visszahelyezve. A reformáció korában Luther és követôi pontosan ugyanígy tekintettek magukra: csak az ôsi, „apostoli” egyház életéhez és szellemiségéhez kívántak visszatérni.

A reformáció azonban a kezdet kezdetétôl összekapcsolódott és kölcsönhatásban volt egy új világrenddel, amelyek a Kolumbusz Kristóf által megkezdett felfedezésekbôl következtek, tudniillik az európai kontinens térbeli befolyása megsokszorozódott, a felfedezések következtében kialakulóban volt egy új (globális) gazdasági rend. Szellemi értelemben pedig nem lehet eléggé hangsúlyozni azt az új kulturális rendet, amelyet a könyvnyomtatás hozott el. A reformáció viharos és gyors terjedése elképzelhetetlen az akkor Európa-szerte gomba módra elszaporodó nyomdák nélkül (MacCulloch, 2011:102-151; Chadwick, 2003:9-28). A téma kiváló hazai kutatója, Birkás Antal szerint habár a földrajzi felfedezések és a korszak általános szellemi pezsgése hozzájárulhatott a reformáció sikeréhez, de ô maga nem ért egyet azzal a Max Weber által felállított tézissel, hogy a kapitalizmus közvetlenül a protestantizmusnak köszönheti a létét (Birkás, 2011:31-32).

Nagyon fontos kiemelni, hogy az a szellemi megújulás, amelyet a humanizmus és a reformáció hozott el, folyamatosan a közelgó apokalipszistôl való félelem árnyékában zajlott. Az 1500-as év fordulójával felerôsödtek a világvégére vonatkozó várakozások, azonban volt egy ennél sokkal megfoghatóbb egzisztenciális fenyegetés Európával szemben: az oszmán-török hódítások. A korszak köznépe és a szellem emberei (miközben Európa uralkodói látszólag nemtörôdöm módon az egymással való vetélkedéssel voltak elfoglalva) egyre szorongatóbbnak érezték a közelgó pogányság fenyegetését. A reformátorok közül nem is kevesen vélték úgy, hogy elérkeztek az utolsó idôk, és a reformáció legradikálisabb képviselôi szerint most kell a hitet új alapokra helyezni, mielốtt minden lélek végsố mérlegre tétetik.

A reformáció gondolatkörében nagyon fontos a Szent Ágoston-i kegyelemtan kiemelése. Ennek jelentôségét nem lehet alábecsülni a világi hatalom és az egyéni megváltás kérdését tekintve. Szent Ágoston Szent Pál nyomán azt vallja, hogy a kegyelem Isten ingyenes adománya, amelyre az embernek szinte nincs is befolyása: „Tehát urunk, Jézus Krisztus által kell megértenönk Isten kegyelmét, egyedül a kegyelem szabadítja meg az embert a búntốl, e nélkül nem tesz semmi jót sem gondolatban, sem akarat, sem szeretet, sem cselekvés révén, és nem csak azért, mert a kegyelem útmu- 
tatása szerint tudják, mit kell tenniük, hanem azért is, hogy segítségével szeretettel tegyék azt, amirôl tudják, hogy meg kell tenniük” (Szent Ágoston, 2015:72). A fenti állásponttal Szent Ágoston nincs egyedül a keresztény hagyományban, sốt évszázadok múlva még Aquinói Szent Tamás is jelezte, hogy a kor vallási életének külsôségeihez képest vissza kellene térni a mélyen megélt spirituális hithez (MacCulloch, 2011:185).

\section{LUTHER MÁrton ÉS A „KÉT BIRODALOM” TAN}

Luther Márton (Martin Luther, 1483-1546) politikai gondolkodásra vonatkozó múvei inkább alkalmi jellegú tanácsadó múvek voltak, amelyekbôl azonban egy határozott tan körvonalazódik. Luther a világi és szellemi kormányzatra vonatkozó politikai teológiájának bemutatásához két írását, az 1523-as A világi felsôségrốl címú, János szász hercegnek ajánlott esszét és az 1526-os, Kram Aszkanius lovagnak címzett A katonai hivatásról szóló munkát használnám fel.

Luther egész politikai gondolkodását meghatározta az az alapgondolat, miszerint az ember a búnbeeséssel elveszítette az eredeti természetét, ennélfogva a kegyelem és a megváltás elérésére önerejéból már nem képes. Szent Ágoston hatását jelzi a búnbeesés központi jellege és a „két birodalom” tan is, amelyet $A$ világi felsôségról címú múvében így foglal össze: „Ádám gyermekeit és az összes embereket két részre kell osztanunk; egyik részét Istenországába, másik részét a világ birodalmába. Kik Istenországába tartoznak, ezek azok, kik Krisztusban igazán hisznek, s ezek Krisztus alattvalói, mert Krisztus az úr s király Istennek országában, miként azt a II-ik zsoltár (6) és az egész írás mondja; s ố azért jött, hogy Istenországát kezdje s e világban létesítse - Annálfogva mondja Pilátus elôtt is: »Az én országom nem e világból való, hanem, aki az igazságból van, hallja az én beszédemet. «S az evangéliomban mindig felvonultatja az Istenországát, és így szól: »Térjetek meg, mert eljött a mennyekországa «, s épúgy: »Keressétek előbb a mennyekországát s annak igazságát«. És nevezi az evangéliomot Istenországa evangéliomának, mivelhogy Istenországát tanítja, kormányozza és fenntartja” (Luther, 1906:369).

Tehát Luther szerint az emberiség két birodalomhoz tartozik: a világi birodalomhoz és „Istenországához”. A fenti szöveghely alapján megállapítható, hogy Luther szerint a világi felsôség, vagyis a politikai hatalom „a világ kezdetétôl” létezik (Luther, 1906:366), mégpedig „Istenországa” mellett. Azonban a két ország Luthernél nem áll olyan duális ellentétpárban, mint Szent Ágostonnál, sốt valójában mind a kettô Isten rendeléséból való, de teljesen más a szerepe a keresztyének életében. Luther szerint az Isten országában a törvényt, amelyen elsôsorban az evangéliumi törvényeket kell érteni, az emberek önkéntesen megtartják, sốt a szeretet törvényéból következóen sokkal többet is adnak, mint amit a világi törvények előírnak. Ezzel szemben a „világ birodalmában”, tehát a fejedelmi hatalom fennhatósága alatt érvényesített törvények rendeltetése, hogy külsôleg kényszerítsék az embereket a rossz cselekedetektôl való tartózkodásra. Ennek oka Luther szerint a következô: „Mivel pedig a természettôl fogva egy ember sem keresztyén vagy kegyes, hanem mindnyájan búnösök és gonoszak, azért az Isten a törvény által tiltja ôket attól, hogy a magok gonoszságát tetszés szerint cselekedeteikkel külsőleg nyilvánítsák” (Luther, 1906:370). 
Az emberi természet olyannyira romlott Luther szerint, hogy a világi kényszerítô erô nélkül képtelen lenne a rossz cselekedetektől való tartózkodásra, így a világi felsôség létezése szükségszerú. Ezért a földi világi hatalom megléte nem valami defektus, nem a „sátán birodalma”, ahogy azt például a katar eretnekmozgalmak vallották, hanem Isten döntése: „A világi jog és hatalom isten akaratából és rendelésébôl van a világon” (Luther, 1906:366). Az „Istenországa” elsôsorban szellemi jellegú, a keresztyének közötti viszonyokra vonatkozik, de a búnbeesés miatt már nem lehet tisztán evangéliumi alapon kormányozni, mert a világi kényszer nélkül az emberek nagy többsége rossz útra térne (Luther, 1906:371-372).

Luther szerint habár mind a két kormányzat, tehát a világi és az isteni ugyanolyan fontos, és egymásra épül, a kettôt azonban el kell egymástól választani. A világi felsôség a fejedelmeket illeti meg, az isteni vagy szellemi kormányzat pedig a klérushoz tartozik (Luther, 1906:372-373). Ez a két hatalom végeredményben azonban ugyannak az éremnek a két oldala, mert mind a két hatalom Istentôl ered, a világi hatalom egy „felülrôl származtatott szuverenitás” (Birkás, 2011:42).

Isten országa nem politikai jellegú entitásként jelenik meg: „Mik tehát a papok és a püspökök? Felelet: Az ô kormányzásuk nem felsôség vagy hatalom, hanem szolgálat és hivatás, mert ôk nem állnak magasabban, s nem jobbak más keresztyéneknél. Ez okból sem törvényt, sem tilalmat nem szabhatnak másoknak az ô akaratuk s engedélyük nélkül. Az ô kormányzásuk semmi más, mint Isten igéjének terjesztése, hogy a keresztyéneket vezessék, az eretnekeket meggyôzzék. Mert, mint mondottuk, a keresztyéneket semmi mással sem lehet vezetni, mint csupán Isten igéjével. Mert a keresztyéneket hit által kell kormányozni s nem külsố cselekedetekkel” (Luther, 1906:398).

Nagyon fontos, hogy Luthernél a világi hatalom és erószak gyakorlása mindig „hivatalhoz" kapcsolódik, tehát a megtorlás és a kényszerítés itt egyrészt professzionális, másrészt valamiféle formális felhatalmazáson alapul (Luther, 1910:9-10). „Summa summarum: a dolognak a veleje ez: a kard hivatala magában véve helyes, isteni és szükséges intézmény, amely nem megvettetést, hanem félelmet, tiszteletet és engedelmességet kíván, mert különben a bosszúnak megállója lesz, mint azt Pál apostol mondja (Róm 13). Mert kétféle felsôbbséget rendelt az Isten az emberek között, az egyiket lelkinek rendelte igéjével és kard nélkül, hogy ez által az emberek jámborokká és igazakká legyenek, és ezzel az igazságossággal elnyerjék az örök életet” (Luther, 1910:12).

A világi hatalom, a kard hatalma arra szolgál, hogy azokat, akik nem kívánnak jámborrá lenni, arra kényszerítse óket, hogy legalább külsôleg így tegyenek (Luther, 1910:9-13). A világi hatalomnak nincs befolyása az emberek megigazulására, nem is feladata, de a rend és a békesség érdekében muszáj erőszakot alkalmazni, és érvényesíteni a jogrendet. Luther nyilvánvalóan igazi és kényszer nélküli hitet vár el, mert az Isten igéje nem lehet jelen abban, aki csak a világi hatalom fenyegetése miatt hisz. „Hogyha emberi törvényt hoznak a lelkekre, hogy ilyen, vagy amolyan módon higyjenek, mint ahogy azt egy vagy más ember előadja, ott bizonyosan hiányzik az Isten igéje. Ha Isten igéje hiányzik belôle, kétséges, hogy vajjon akarja-e azt az Isten, mert amit nem ô parancsol, arra nézve nem lehetünk bizonyosak, hogy tetszik neki, sôt 
bizonyosak vagyunk, hogy Istennek nem tetszik. Mert ő a mi hitünket csupán s tisztán az ô isteni igéjére akarja alapítani” (Luther, 1906:386-387).

\section{Kálvin János a polgári kormányzatról}

Huldrych Zwingli (1484-1531) halála után a francia származású Kálvin János (Jean Calvin, 1509-1564) lett a svájci protestantizmus vezéralakja. Kálvin nem volt teológus (jogásznak tanult), ennek ellenére, amikor 1536-ban Genfbe került, egyértelmúen a hitélet megújítójaként lépett fel; mindezek mellett talán jogászi végzettsége okán is az államra és a politikára vonatkozó gondolatait sokkal finomabban és a hatalom intézményi aspektusaira érzékenyen elemezte. Míg Luther egyértelmúen a lelkiség, a világi és spirituális hatalom „illetékességének” elválasztását, addig Kálvin a két uralom közös gyökerét és szükségszerú együttmúködését hangsúlyozta (Birkás, 2011:98).

Kálvin gondolkodásának egyik kulcsfogalma Isten abszolút szuverenitása, amely az egész teremtett világra vonatkozik: nem csupán az ember belsố világára, hanem a külsô (polgári) világra is. Az isteni szuverenitás azt jelöli, hogy Isten akarata mindig érvényesül, ahogy Frivaldszky János fogalmaz, „a teremtőnek a teremtés Királyának tulajdonjoga van minden teremtménye felett, így az ember felett is, ami a kálvini terminusokban azt jelenti, hogy a Király akarata határozza meg az alattvaló akaratát, az ember privilégiuma pedig az engedelmesség” (Frivadszky, 2013:154). A búnbeeséssel az emberek kikerültek a tisztán isteni kormányzás alól, a lázadó ember így kettôs kormányzás alá kerül. Isten abszolút akarata uralja a teremtést, amely „szuverénként” uralkodik; akarata nem csupán abszolút, hanem rendezett is, a dolgok nem pusztán attól helyesek és jók, mert az isteni akarat pecsétje van rajtuk, hanem ebben egyfajta elrendezettség (ordo) van. Ez az isteni szuverenitásból származó állam, következésképp a polgári kormányzat szuverenitása (Kuyper, 2001:83). Ezen a ponton fontos felhívni a figyelmet a jogtudomány és a protestáns teológia közötti kapcsolatra. Kálvin jogászi végzettségének hatása látványosan megmutatkozik az isteni szuverenitás leírásában. Amint arra Frivaldszky János is rámutat, Kálvin nagyon színes és precíz jogi szakkifejezésekkel írja le: Istennek kizárólagos hatalma van az alattvalói felett (Frivadszky, 2013:156).

A kálvini teológia központi fogalma Kuyper szerint „a Szentháromság Istenének a teljes világegyetem fölött való szuverenitása”, s e mindent átfogó szuverén isteni akarat alatt három „felsôség” formájában nyilvánul meg az emberi világban: „1. szuverenitás az államban, 2. szuverenitás a társadalomban, 3. szuverenitás az egyházban" (Kuyper, 2001:79). Ezek a származtatott szuverenitások szervesen illeszkednek a kálvini etikához, ugyanakkor érvényük csak relatív, mivel csak a „saját területükön” élveznek önállóságot.

Kálvin politikai teológiájának alapállítása: az állam léte Isten adománya, az állam rendeltetése az, hogy a búnben éló embert a jóra vezesse. Ha nem történt volna meg a búnbeesés, akkor a mai napig Isten szuverenitása alatt állna az ember, és az ó alattvalója lenne. „Ezt Pál is világosan tanítja (Róm 12,8), mikor az elöljáróságokat Isten ajándékai közé számítja, amelyek bár a kegyelem különbözôségéhez képest különbözôképpen vannak kiosztva, Krisztus szolgái által az egyház építésére kell fordítaniuk. 
Mert ámbár azon helyen tulajdonképpen a tekintélyes férfiak tanácsgyúlésérôl beszél, amelyeket az ôsi egyházban állítottak fel, hogy a közfegyelem gyakorlásának élén álljanak, amely hivatalt a korinthusiakhoz írott levelében (1Kor 12,28) kormányzásnak nevez, mégis mivel látjuk, hogy a polgári kormányzat célja is ide irányul, kétségtelen, hogy az igazságos elöljárónak minden nemét ajánlja nekünk. De még sokkal világosabban tanítja a dolgot ott, ahol azt alaposan megvitatja” (Kálvin, 1994:750-751).

Az állam isteni eredete azonban nem fajul el a teokrácia nyílt kimondásába, éppen ellenkezóleg, mivel a földi polgári kormányzat ugyanúgy a búnös világ része, és ugyanúgy búnös emberek múködtetik, szükségszerú, hogy meglegyenek a maga veszélyei. Ahogy Kuyper fogalmaz: az állam egyszerre áldás és örök veszélyforrás, egy mankó, amely segít, de képes tovább nyomorítani. Mindannyian Isten abszolút szuverenitásának alattvalói vagyunk, így „e sok-sok államnak voltaképpen nem szabadna léteznie, csakis egyetlen világbirodalomnak kellene, hogy létjogosultsága legyen” (Kuyper, 2001:81). A búnös voltunk miatt azonban szükségszerú, hogy így szétszabdalva, világi kormányzatok hatalma alatt álljunk, mert enélkül a földi lét maga lenne a pokol (Kuyper, 2001:81). Kálvin és követôi azonban Lutherhez képest sokkal árnyaltabban tekintenek a világi hatalom túlkapásaira, tisztában vannak azzal, hogy ebben a búnös földi világban a hatalom birtokosai könnyedén válhatnak zsarnokokká (Kuyper, 2001:82).

Az emberek világában, mint írtuk, háromféle istentôl származtatott szuverenitás van: az elsố az állam (polgári kormányzat) szuverenitása. Kálvin szerint a polgári kormányzat egyrészrôl teljesen természetesen jött létre, másfelôl nagyon más, mint az isteni lelki kormányzat. A lelki kormányzat az örökkévalóságra, az ember üdvösségére irányul, a polgári kormányzat a múlandó testi világot irányítja. Luthernél a kettôs ország ténylegesen megosztja az embereket. Az emberek egyik része a világi birodalomba tartozik, ezeket kényszeríteni kell a helyes cselekedetekre, míg a másik rész igaz keresztyénként belsôleg követi az evangéliumi törvényeket, és csupán alávetik magukat a világi felsôségnek. Ezzel szemben Kálvin szerint magában az egyénben található meg ez a kettôs kormányzat, s az eltérô szóhasználat is jelzi, hogy a két szféra között sokkal dinamikusabb kölcsönhatás van, mint Luthernél.

Luthernél a világi hatalom kényszere a „gonoszok ellen” szükségszerú, hacsak nem keresztyének, akiknek ilyen hatalom közbelépésére nincs szükségük ahhoz, hogy az evangéliumi törvényeket betartsák, és azok szerint éljenek a közösségben. Kálvinnál másképpen áll a helyzet. A kiindulópont itt is az ember búnös természete, azonban az ember eredendô méltóságából vagy istenképmásiságából és igazságosságából megốrzött annyit, hogy „Isten kegyelmének (gratia communis) közbelépésre révén a lényegi istenkép megmaradt, ezáltal az ember most is rendelkezik, ha nem is eredeti, de a polgári élet számára elégséges igazságossággal (iustitia civilis) és méltósággal” (Frivaldszky, 2013:154).

Kálvinnál a polgári kormányzat nem csupán azt a célt szolgálja, hogy megtorolja a rossz cselekedeteket, vagy fenntartsa a rendet. Pál apostol ,azt tanítja, hogy a hatalmasság is Isten rendelése, és nincs semmiféle hatalom, hanem csak amit Isten rendelt (Róm 13,1). Maguk a fejedelmek pedig Isten szolgái a jól cselekvóknek dicséretére, a gonoszoknak, mint bosszúállók, rettegésükre” (Kálvin, 1994:751). 
Az isteniból lefelé háramló szuverenitás második formája a társadalomban megnyilvánuló szuverenitás. Itt a társadalmi létezés állami szuverenitáson kívüli szféráiról van szó, amelyek túl vannak az állami szuverenitáson: a családról, a munkáról, a tudományról, a múvészetrôl és minden olyan, az emberek közösségi életét érintô szféráról, melyek önállóságát nem az állam, hanem az isteni szuverenitás szavatolja (Kuyper, 2001:91). A társadalom e kis köreinek önálló, államhatalomtól való függetlenségének elismerésével gyakorlatilag a kálvini szociális gondolat megelôlegezi a civil szféra függetlenségét és néminemú szembenállását az államival szemben (Kuyper, 2001:91-92). A kálvini predesztináció elvének volt egy olyan határozottan világi-szociális vonzata, amelyre Max Weber klasszikus munkája, A protestáns etika és a kapitalizmus szelleme is felhívja a figyelmet. Ez a „hivatás” és a polgári életben elvégzett felelósségteljes munka olyan túlvilági jutalmakkal jár, amelyek a korábbi katolikus gondolkodásmódtól teljesen idegenek voltak (Weber, 1995:83). Ezeket a szférákat, mint az egyetemek, céhek, egyesületek és a család is, a polgári kormányzatnak tiszteletben kell tartania, mert ezek olyan „múködési területek”, amelyek relatív autonómiával rendelkeznek (Kónya, 1979:343). „Az államhatalom képtelen érvényesíteni a maga törvényeit mind a négy területen, és ezért tiszteletben kell tartania az élet legbensô, természetes törvényszerúségeit. Isten ezeken a területeken is éppoly teljesen és korlátlan módon uralkodik az ó választott mesterei által, mint ahogy az állam területén is hatalmat gyakorol választott elöljáróin keresztül” (Kuyper, 2001:97). A kálvini tanban azonban ez nem jelenti azt, hogy az államnak itt ne lenne semmilyen keresnivalója. Ellenkezóleg, az állam felelôsséggel tartozik a relatíve autonóm társadalmi területek létezéséért, zavartalan múködéséért. Egyrészt e szférák közötti ütközések és konfliktusok esetén be kell avatkoznia a határok betartása érdekében, védelmeznie kell az egyéneket és a gyengéket a többség hatalmával szemben, továbbá e szférák múködésének a teljes társadalmi béke és rend szolgálatában kell állnia, mert végsố soron az isteni világrendben ezek a társadalmi területek is az ember örök üdvösségét szolgálják. Az állam, a polgári kormányzat e beavatkozása azonban szigorúan jogi keretek között kell hogy végbemenjen (Kuyper, 2001:98).

\section{A TOLERANGIÁTÓL A GONDOLATSZABADSÁGIG}

A fentiekból határozottan körvonalazódik az, hogy a reformáció korának két legnagyobb hatású gondolkodója számára a világi kormányzat és a lelki-spirituális kormányzat egyértelmúen elkülönül egymástól, és nem ugyanazt a célt szolgálja, nem is képes ugyanazt a célt szolgálni. A világi kormányzat a földi világ rendjét védi, amelyet a bûnbeesés indokol. A bún üldözése és megtorlása az, amelyért léteznie kell itt a földi világban az államnak, és nem azért, hogy az egyén megváltásáért tegyen. Ezt jól jelzi az, hogy Luther szerint ha a világi hatalmasságok mégis beavatkoznak a hit dolgaiba, akkor nem lehet ellenük fellázadni, hanem egyszerúen odébb kell menni, ahol a keresztyének meg tudják élni a hitüket. Ebból következik, hogy az egyénnek nem lehet elvárása a világi hatalom felé az ô túlvilági céljai elérése okán, és a világi hatalom sem avatkozhat bele a klérus ügyeibe. Sót, a klérus nem múködhet politikai entitásként. 
Ennek a gondolatnak a jelentôségét nem lehet eléggé hangsúlyozni, és álláspontom szerint pontosan itt van a lényeges különbség, ha középkor és a kora újkor állam-egyház diskurzusát meg akarjuk különböztetni: a középkorban a regnum és a sacerdotium viszonya mindig hatalmi kérdés volt. A középkori politikai gondolkodás szinte végig ama kérdés körül forgott, hogy a két hatalom közül melyiknek van elsôbbsége, és melyik hatalom melyikból származik.

Luther és Kálvin abból a szempontból nem törte meg a középkori keresztény paradigmát, hogy a földi és a spirituális világ ugyanannak a teremtett rendnek a részeiként léteznek, azonban ez a két birodalom vagy két kormányzás mégis elválik egymástól, egyiknek a másik felett nincsen hatalma, mert nem ugyanazon a létszférán belül mû́ködnek. A világi hatalom a földi világban kívánja az isteni rendnek megfeleló békét és rendet fenntartani; a klérus pedig habár a földi világban múködik, transzcendens célokért küzd.

A témakör spirituális és egyházi oldalát elengedve most már csak a világi hatalom szemszögébốl vizsgálnám a kérdést. A világi hatalomnak nincsenek eszközei az üdvözüléshez, mert a megváltás az eleve elrendelés tana miatt Isten kezében van (vagy volt, ha már a teremtés kezdetén eldôlt, hogy a léleknek mi a sorsa). Másrészt a lelki élet nem hozzáférhetố a világi hatalom számára, amelyet a protestáns Hollandiában alkotó Benedictus de Spinoza a következóképpen fogalmazott meg nagy hatású múvében már a 16. században: „,L]ehetetlen, hogy a lélek teljesen másvalakinek a joga alatt álljon. Mert természeti jogát, vagyis azt a képességét, hogy szabadon okoskodjék és bármirôl ítélkezzék, senki sem ruházhatja át másra, s erre nem is kényszeríthetô. [...] Bármennyire is áll tehát, hogy a legfóbb hatalomnak joga mindenre kiterjed, s hogy a jog és jámborság értelmezőinek tartják óket, azt mégsem érhetik el sohasem, hogy az emberek ne a saját gondolkodásmódjuk szerint alkossanak maguknak véleményt a dolgokról, s ehhez képest ne ilyen vagy olyan indulat támadjon bennük" (Spinoza, 1984:291-292).

A fenti, Spinoza által írott sorok késôbb John Locke Levél a vallási türelemröl címú mû́vében (Locke, 1982) találnak visszhangot, és készítik elố azt a transzformációt, amely során a vallási türelem és tolerancia, amelynek szükségességét a reformáció teremtette meg, késôbb a gondolatszabadságként nyerjen új megfogalmazást, sokkal általánosabb értelemben.

A reformáció korának gondolkodói még egy különös és átmeneti korszak gyermekei, habár a „hit akarása” minden protestáns gondolkodónál és prédikátornál erôs, de paradox módon a reformáció volt az európai kultúrtörténetben az a katalizátor, amely a kultúra különbözố szféráinak autonómiáját lehetôvé tette. A politikai szféra önállóságát már Machiavelli megfogalmazta indirekt módon (Machiavellinek $A$ fejedelem címú múve explicit módon nem mondja ki a politika és az erkölcs arisztotelészi egységének felmondását, azonban majd minden megnyilvánulása ezt jelzi: vö. Machiavelli, 1978:51-57., ill. Antalffy, 1986), de a reformáció képes volt arra, hogy a hit mellett a lét többi szférájának autonómiáját megerôsítse. A világi és spirituális hatalom céljainak differenciálása lehetôvé tette, hogy az emberi lét értelmének különbözô rétegeit egymásra párhuzamosan képesek legyünk leírni. Különösen Kálvin János munkássága 
a példa arra, hogy az emberiben lévô belsô kormányzás (kegyelem) és a külsô kormányzás (a polgári lét jótéteményei) milyen egységet képes teremteni. Mannheim Károly szerint a modern kultúrafogalom csak onnantól létezhetett, amikor a kultúra kikerült a vallási szféra irányítása alól (Mannheim, 1995:26), és ennek a munkának az eszmei alapjait a reformáció korában tették le.

Ha jelen gondolatoknak lehet bármilyen univerzálisabb aktualitást kölcsönözni, akkor felvetődhet a kérdés: ha az emberi lélek és annak boldogsága olyannyira hozzáférhetetlen, és a boldogság olyan sokféle lehet, vajon a „jó államnak és a jó kormányzásnak” milyen lehetôségei lehetnek arra, hogy a polgárait boldogabbá tegye? Fel lehet-e egyáltalán még vetni ezt a kérdést?

\section{JEGYZETEK}

1 A tanulmány a 2017. november 22-23-án szervezett, az Államelmélet alapkérdései II. elnevezésû konferencián elhangzott elôadás tanulmánnyá bôvített változata. A mú a KÖFOP-2.1.2-VEKOP-15-2016-00001 azonosító számú, A jó kormányzást megalapozó közszolgálat-fejlesztés elnevezésú kiemelt projekt keretében mûködtetett Ludovika Kiemelt Kutatómúhely keretében, a Nemzeti Közszolgálati Egyetem felkérésére készült.

\section{FELHASZNÁLT IRODALOM}

Antalffy György (1986): Machiavelli és az állam tudománya. Közgazdasági és Jogi Könyvkiadó, Budapest.

Birkás Antal (2011): Reformáció, államhatalom, politika. Luther és Kálvin jogfilozófiai és politikai filozófiai nézetei. Luther Kiadó, Budapest,

Canning, Joseph (2002): A középkori politikai gondolkodás története 300-1450. Osiris, Budapest.

Chadwick, Owen (2003): A reformáció. Osiris, Budapest.

Diarmaid MacCulloch (2011): A reformáció története. Európa Könyvkiadó, Budapest.

Frivaldszky János (szerk.) (2013): A jogi gondolkodás mérföldkövei. Szent István Társulat, Budapest.

Kálvin János (1994): A keresztyén vallás rendszere II. Kálvin Kiadó, Budapest.

Kónya István (1979): Kálvinizmus és társadalomelmélet. Akadémiai Kiadó, Budapest.

Kuyper, Abraham (2001): Kálvinizmus és modernitás. Hat előadás. Koinónia, Kolozsvár.

Locke, John (1982): Levél a vallási türelemról. Akadémiai Kiadó, Budapest.

Luther Márton (1906): A világi felsôségrôl. In: D. Luther Márton egyházszervezố iratai 3. Szerk. Dr. Masznyik Endre, Luther Társaság, Budapest.

Luther Márton (1910): A katonai hivatásról. In: D. Luther Márton egyházszervezố iratai 5. Szerk. Dr. Masznyik Endre, Luther Társaság, Budapest.

Machiavelli, Niccolò (1978): A fejedelem. In: Machiavelli Múvei I. Európa Könyvkiadó, Budapest.

Mannheim Károly (1995): A gondolkodás struktúrái. Kultúraszociológiai tanulmányok. Atlantisz Könyvkiadó, Budapest.

Pierrard, Pierre (1994): A katolikus egyház története. Agapé, Szeged.

Spinoza, Benedictus de (1984): Teológiai-politikai tanulmány. Akadémiai Kiadó, Budapest.

Szent Ágoston (2015): De correptione et gratia. In: Írások a kegyelemrôl és az eleve elrendelésrôl. L’Harmattan Kiadó, Budapest.

Weber, Max (1995): A protestáns etika és a kapitalizmus szelleme. Cserépfalvi, Budapest. 